\title{
SHARE OF FOOD EXPENDITURE IN ROMANIA COMPARED TO OTHER EU COUNTRIES AND THE ESTIMATES OF ITS EVOLUTION UNTIL YEAR 2035
}

\section{UDEO TROŠKOVA HRANE U RUMUNIJI U ODNOSU NA DRUGE ZEMLJE EU I PROCENA NJEGOVOG RAZVOJA DO 2035. GODINE}

\author{
Adrian BĂNEȘ*, Manuela-Dora ORBOI ${ }^{* *}$, Vasile GOȘA* \\ *Romanian Academy-Timisoara Branch, Bv.Mihai Viteazu 24, 300223 Timisoara, Romania \\ Banat's University of Agricultural Sciences and Veterinary Medicine

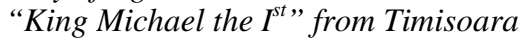 \\ e-mail: abanes@gmail.com
}

\begin{abstract}
Food consumption is an element that directly reflect the living conditions of the population, so the proportion spent on food consumption of the total expenses of a person can be an indicator of standard of living in that country.

The present work performed a comparative study between food spending as a share in Romania and several EU countries. Also, it is performed an estimate of future development thereof, until the year 2035. Using Pearson correlation between total income as the independent variable and the share of food products expenditures from total consumption expenditure (\%) as the dependent variable, results an inverse correlation between the two variables, rising incomes decrease the share of food expenditure. France in 1960 had values close of Bulgaria in 2015, decreasing at present day to 20.4\% and Germany in 1950 was situated close to the value of today's Romania (44\%), in 2015 decreasing to $13.6 \%$.

Considering the current trend of revenue growth, we estimate a decrease in the share of expenses for food around 39\% by the year 2035. This decrease is not enough, so we made several scenarios for revenue growth, the 7-8\% bringing with them a decrease in the share spent on food to values of $30-33 \%$.
\end{abstract}

Key words: Food consumption, food expenditure, estimates of food expenditure.

\section{REZIME}

Potrošnja hrane je element koji direktno odražava životne uslove stanovništva, tako da udeo potrošnje hrane u ukupnim troškovima osobe može biti pokazatelj životnog standarda u toj zemlji.

U ovom radu je obavljena komparativna studija udela potrošnje hrane u Rumuniji i nekoliko zemalja EU. Takođe, obavljena je procena njegovog budućeg trenda do 2035. godine. Koristeći Pearsonovu korelaciju između ukupnog prihoda kao nezavisne promenjljive i udela troškova prehrambenih proizvoda od ukupne potrošnje (\%) kao zavisne promenjljive, rezultira inverznom korelacijom između ove dve promneljive. Povećanje prihoda smanjuje udeo potrošnje hrane. Francuska je 1960. godine imala ovaj udeo slično kao Bugarska u 2015, s obzirom da je u ovom trenutku smanjena na 20,4\%, a Njemačka 1950. bila je blizu vrednosti današnje Rumunije (44\%), u 2015. godini je 13,6\%.

S obzirom na trenutni trend rasta prihoda, procenjuje se smanjenje učešća troškova hrane za oko 39\% do 2035. godine. Ovo smanjenje nije dovoljno, tako da je napravljeno nekoliko scenarija za rast prihoda, 7-8\% koji će doneti smanjenje udela potrošenje na hranu na vrijednosti od 30-33\%.

Ključne reči: Potrošnja hrane, troškovi hrane, procena troškova hrane.

\section{INTRODUCTION}

Food consumption is an element that reflects the living conditions of the population, so that the proportion spent on food consumption may be an indicator of quality of life in that country. In support of the above, the author Cătălin Avramescu states: "Starting from Engel's Law, we can estimate the degree of development of an economy. Where we see only a small proportion of that income is swallowed up by food costs that mean that the economy is performing and generating significant revenues." (http://www.bursa.ro, Avramescu C., 2015). This paper presents results of research conducted in order to find opportunities to near Romania's living standards to that of developed countries of Europe in a time horizon of 20 years (the initial year is 2015), according to a project developed by the Romanian Academy on Security and food safety, with direct reference to spending food consumption. A fair number of authors have dealt with the forecast in agriculture, analyzing the time series of the production and the price (Mutavdžić et al, 2016). This approach, in our view, can be achieved by increasing individual population income, which draws implicitly diminishing share of food consumption expenditures.

\section{MATERIAL AND METHOD}

In the nineteenth century, Ernst Engel, found a rule that now bears his name (Engel's law) and showing that when household income increases, the share of food expenditure in these revenue decreases (Rujescu et al, 2016). To carry out research, we analyzed the monthly revenues, total expenditures, consumer spending, consumer spending for food consumption and share of food expenses in total consumption expenditure of the population. The period under consideration varied according to data provided by websites with statistical data, but in all cases was at least 5 years. The data used were taken from international and national statistics, as well as from various national and international publications, on which we made own calculations and interpretations (tables 1, 2, 3 and 4). The available hard data have been verified through the Pearson correlation results corresponding to the law formulated by Engel. Next, using regression functions we simulated different patterns of variation of the above indicators, which were compared with the level achieved or envisaged of same indicators in Germany and France. The methods used in the preparation of the work were: analysis, synthesis, comparison and forecast based on regression functions. 
Table 1. Structure of incomes and expenditure in Romania, per capita

\begin{tabular}{|c|c|c|c|c|c|c|c|c|c|c|c|c|c|c|c|}
\hline & 2001 & 2002 & 2003 & 2004 & 2005 & 2006 & 2007 & 2008 & 2009 & 2010 & 2011 & 2012 & 2013 & 2014 & 2015 \\
\hline Total Income, $€$ & 69,5 & 73,2 & 75,6 & 90,8 & 113,9 & 134,3 & 173,1 & 198,6 & 188,2 & 188,9 & 198,1 & 193,3 & 202,7 & 211,0 & 227,4 \\
\hline $\begin{array}{l}\text { Total consumption } \\
\text { expenditure, } €\end{array}$ & 50 & 53 & 54 & 63 & 81 & 93 & 113 & 127 & 119 & 122 & 126 & 126 & 132 & 138 & 144 \\
\hline $\begin{array}{c}\text { Total food } \\
\text { expenditures, } €\end{array}$ & 28,0 & 28,0 & 28,1 & 31,2 & 38,3 & 42,3 & 51,0 & 56,3 & 52,7 & 53,8 & 56,4 & 56,9 & 59,5 & 59,9 & 60,0 \\
\hline $\begin{array}{c}\text { Share of food } \\
\text { expenditure from } \\
\text { consumption } \\
\text { expenditures \% }\end{array}$ & 55,8 & 53,2 & 52,1 & 49,6 & 47,2 & 45,4 & 45,0 & 44,3 & 44,2 & 44,1 & 44,9 & 45,1 & 45,0 & 43,4 & 41,6 \\
\hline
\end{tabular}

Source: www.insse.ro

Table 2. Structure of food consumption expenditure of households in Bulgaria, \%

\begin{tabular}{||c|c|c|c|c|c|c||}
\hline & 2010 & 2011 & 2012 & 2013 & 2014 & 2015 \\
\hline $\begin{array}{c}\text { Total foods and alcoholic, } \\
\text { non-alcoholic beverages and tobacco }\end{array}$ & 40,4 & 39,6 & 36,6 & 36,1 & 35,5 & 34,9 \\
\hline
\end{tabular}

Source: http://www.nsi.bg/en/content/5703/annual-data

Table 3. Share of food consumption expenditures for household in France, \%

\begin{tabular}{|c|c|c|c|c|c|c|c|c|c|c|c|c|}
\hline & 1960 & 1965 & 1970 & 1975 & 1980 & 1985 & 1990 & 1995 & 2000 & 2005 & 2010 & 2014 \\
\hline $\begin{array}{c}\text { Share of food } \\
\text { consumption } \\
\text { expenditures for } \\
\text { household, France, } \\
\%\end{array}$ & 34,6 & 31,3 & 27,6 & 25,5 & 23,4 & 22,7 & 21,7 & 21,1 & 20,7 & 20 & 19,8 & 20,4 \\
\hline
\end{tabular}

Source: https://www.statista.com/statistics/526488/share-food-consumption-disposable-income-france/

Table 4. Share of food consumption expenditures for household in Germany, \%

\begin{tabular}{|c|c|c|c|c|c|c|c|c|c|c|c|c|c|c|c|c|c|}
\hline & 1950 & 1960 & 1970 & 1980 & 1990 & 2000 & 2005 & 2006 & 2007 & 2008 & 2009 & 2010 & 2011 & 2012 & 2013 & 2014 & 2015 \\
\hline $\begin{array}{l}\text { Share of food } \\
\text { consumption } \\
\text { expenditures } \\
\text { for household, } \\
\text { Germany, \% }\end{array}$ & 44 & 38 & 25 & 20 & 17,6 & 14,6 & 14,3 & 14,1 & 14,1 & 14 & 13,9 & 13,5 & 13,3 & 13,3 & 13,4 & 13,5 & 13,6 \\
\hline
\end{tabular}

Source: https://de.statista.com/statistik/daten/studie/75719/umfrage/ausgaben-fuer-nahrungsmittel-in-deutschland-seit-1900/

\section{RESULTS AND DISCUSSION}

According to Engel's law, to have lower food costs, we need more revenue. A link between the two was determined using Pearson correlation, which shows the relationship link, strictly linear, between two variables and the strength of the association between them (Rujescu et al, 2016). Specifically, we examined the correlation between the indicator total income as the independent variable and the indicator expenditure ratio of food in total consumption expenditure as the dependent variable.

From calculations resulted a correlation coefficient of -0.929 (Table 5), which shows that there is a very strong inverse correlation between the two variables, revenue growth lowers the share of food expenditure. Next we searched the most appropriate function to express that correlation. We have tested several functions, logarithmic, exponential and power and because the latter has the highest $\mathrm{R}^{2}$ coefficient (0.92), was used further to achieve the forecasts until 2035 (table 6).

To achieve future determinations and comparisons, we have taken from existing statistical data the share of food consumption for Romania, Bulgaria, France and Germany. Accordingly, Romania and Bulgaria had similar values and developments, as well as France and Germany, but compared to the first half of the values (figure 1). Next, we determined the potential income growth function in Romania to make further correlation with the share of food expenditures.
Table 5. Pearson correlation table for the two variables

\begin{tabular}{|c|c|c|c|}
\hline \multicolumn{4}{|c|}{ Correlations } \\
\hline & & VAR00001 & VAR00002 \\
\hline \multirow{3}{*}{$\begin{array}{c}\text { VAR000 } \\
01\end{array}$} & Pearson Correlation & 1 &,$- 929^{* *}$ \\
\hline & Sig. (2-tailed) & &, 000 \\
\hline & $\mathrm{N}$ & 15 & 15 \\
\hline \multirow{3}{*}{$\begin{array}{c}\text { VAR000 } \\
02\end{array}$} & Pearson Correlation &,$- 929^{* *}$ & 1 \\
\hline & Sig. (2-tailed) &, 000 & \\
\hline & $\mathrm{N}$ & 15 & 15 \\
\hline \multicolumn{4}{|c|}{$\begin{array}{c}\text { **. Correlation is significant at the } 0.01 \text { level (2-tailed). } \\
\text { VAR00001 - Incomes RO, euro } \\
\text { VAR00002 - Share of food expenditure from consumption } \\
\text { expenditures RO, \% }\end{array}$} \\
\hline
\end{tabular}

Table 6. The equation calculated for the two variables Model Summary and Parameter Estimates

\begin{tabular}{|c|c|c|c|c|c|c|c|}
\hline \multicolumn{8}{|c|}{ Model Summary and Parameter Estimates } \\
\hline \multicolumn{8}{|c|}{ Dependent Variable: VAR00002 } \\
\hline \multirow{2}{*}{ Equation } & \multicolumn{6}{|c|}{ Model Summary } & $\begin{array}{l}\text { Parameter } \\
\text { Estimates }\end{array}$ \\
\hline & \begin{tabular}{|c|}
$\mathrm{R}$ \\
Square
\end{tabular} & $\mathrm{F}$ & df1 & df2 & Sig. & Constant & b1 \\
\hline Logarithmic & ,913 & 137,198 & 1 & 13 & 000 & 91,430 & $-8,992$ \\
\hline Power & ,920 & 149,852 & 1 & 13 & ,000 & 117,384 &,- 186 \\
\hline Exponential & ,876 & 91,523 & 1 & 13 & 000 & 57,785 &,- 001 \\
\hline
\end{tabular}




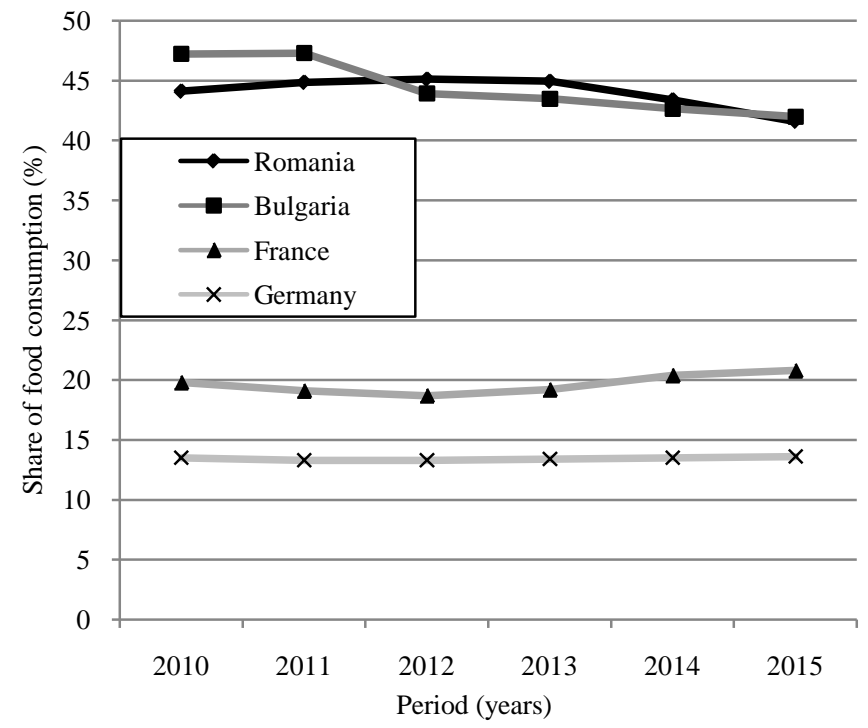

Fig. 1. The evolution of share of food consumption in Romania, Bulgaria, France and Germany, 2010-2015, \%

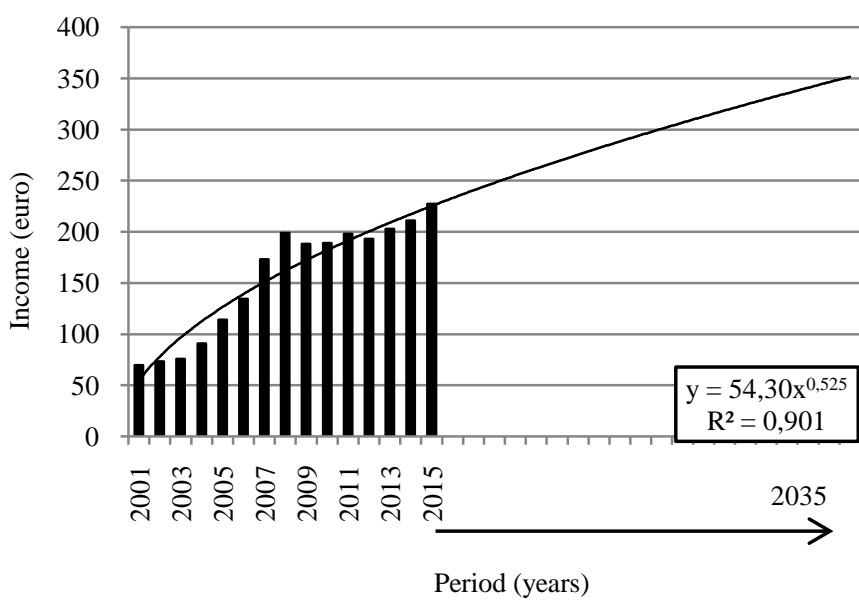

Fig. 2. The power function, calculated on historical data
We also used a power function, calculated on historical data, with forecast for 20 years, the resulting function having a $\mathrm{R}^{2}$ coefficient of 0.9014 , large enough to be considered (figure 2). From the relationship determined above, we calculate the estimation of income per person by year 2035 and the share of food expenditures. It appears that, the revenue growth in line with the current trend, will lead to a value of food expenditures share of $39.5 \%$, i.e. a decrease of 3.3 percentage points compared to reference year 2015.

This decrease is quite small, so we created three scenarios for income growth, with average annual growth rates of 3, 5 and $7 \%$ more than the current trend. For these three scenarios resulted decreases in expenditure ratios to values of 38.3, 35.7 and 33.3, i.e. differences of 4.5, 7.1 and 9.5 percentage points (figure 3 ). On the ordinate axes of the two scenarios were represented the income growth in the euro, at the left and versions of diminishing food consumption expenditure weights in \%, on the right. In all three scenarios, since 2016 was applied the power function with the coefficients determined above (Table 6), values up there being the historical data.

\section{CONCLUSION}

The share of food in total consumer expenditure household consumption expenditure represents the effort made by the population to purchase food and by default, the standard of living of its. To minimize these differences to other developed European countries a solution is the introduction of measures concerning the increase of monthly income per person. This approach, particularly sensitive requires a special ability to avoid skidding that can occur and affect the macroeconomic stability of the country.

On the scenarios presented, it is clear that the first is a variant more pessimistic which does not allow an appropriate decrease of indicator target, an increase in revenues, according to the third scenario (up $7 \%$ ), or if possible even more, even if it is less probable, being a variant desirable and would allow a decrease nearly $30 \%$ in the share of food consumption expenditure.

Regression functions used for anticipating the possibilities of reaching targets in correlation with other economic indicators are

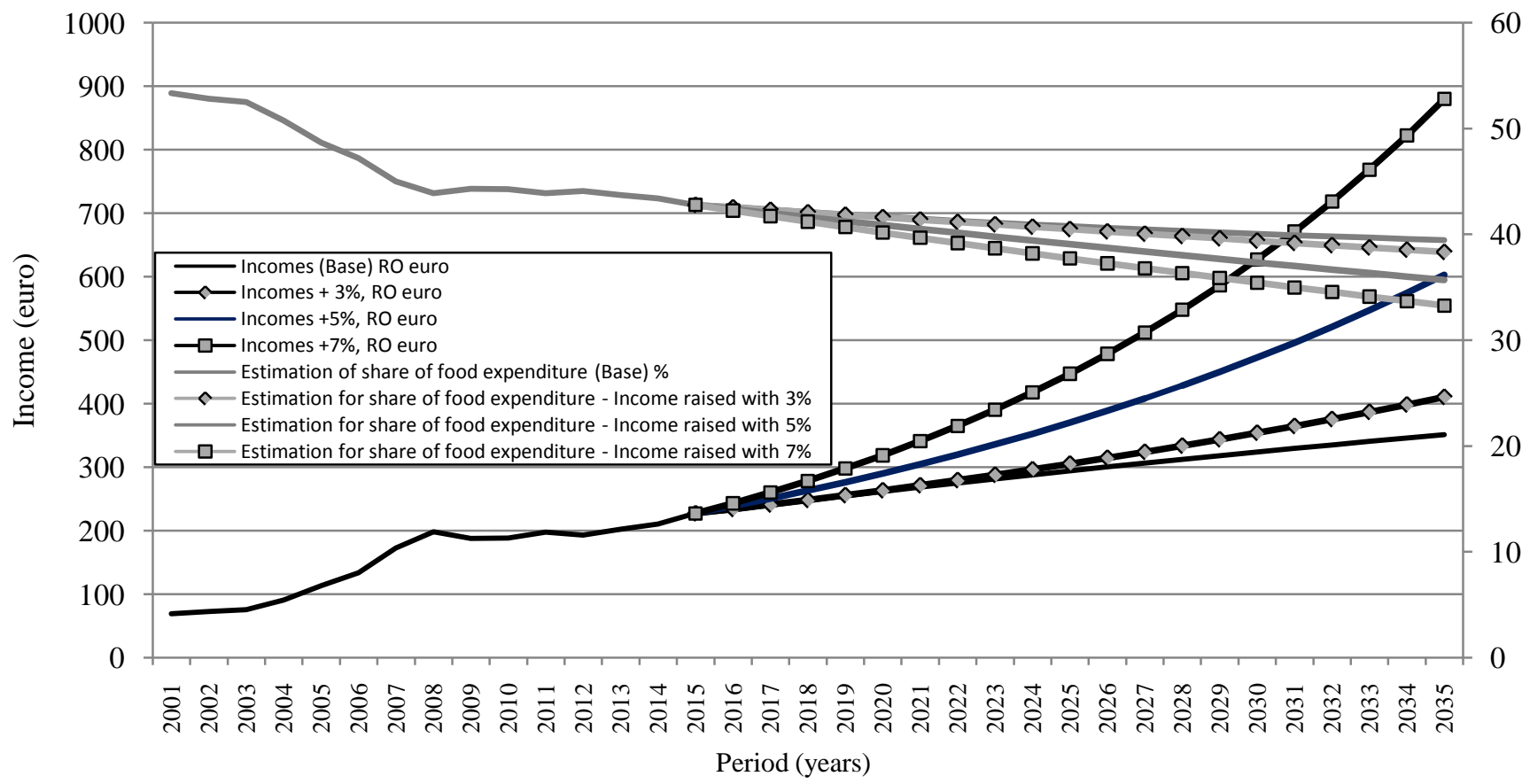

Fig. 3. The 3 scenarios for the share of food expenditures (rise of the incomes with 3.5 and 7\%) 
useful in predicting trends but do not provide certainty of achieving forecasted indicators.

\section{REFERENCES}

Rujescu, C.I., Feher, Andrea, Băneș, A., Otiman, P.I. (2016), Bazele economico-matematice ale unor modele de prognoză a producției și consumului agroalimentar în România, in: Alexandri Cecilia, Gavrilescu Camelia, Kruzslicika Mihaela, Rusu Marioara, Economie agroalimentară și dezvoltare rurală în țările din sud estul Europei: provocări pentru viitor, Editura Academiei Române, București.

Mutavdžić B., Novković N.a, Vukelić Nataša, Radojević V., (2016), Analysis and prediction of prices and price partyes of corn and wheat in Serbia, Journal on Processing and Energy in Agriculture 20, 2, 1821-4487, 20; 2; p106-108.

http://www.bursa.ro, Avramescu C., 07.04.2015.

https://www.destatis.de/DE/ZahlenFakten/GesellschaftStaat/Ein kommenKonsumLebensbe-
dingungen/Konsumausgaben/Tabellen/PK_NGT_EVS.html https://www.destatis.de/DE/ZahlenFakten/GesellschaftStaat/Ein kommenKonsumLebensbeding-

ungen/Konsumausgaben/Tabellen/PrivateKonsumausgaben_D. html

https://de.statista.com/statistik/daten/studie/75719/umfrage/ausg aben-fuer-nahrungsmittel-in-deutschland-seit-1900/ www.insse.ro

https://www.statista.com/statistics/526488/share-foodconsumption-disposable-income-france http://www.tradingeconomics.com/bulgaria/wages ttp://www.tradingeconomics.com/romania/wages http://www.tradingeconomics.com/france/household-finalconsumption-expenditure-per-capita-growth-annual-percentwb-data.html

Received: 28. 02. 2017.

Accepted: 06. 09. 2017. 